\title{
Forfeiture of Illegal Gain: An Economic Perspective
}

\author{
ROGER BOWLES, MICHAEL FAURE \\ $\&$ NUNO GAROUPA*
}

\begin{abstract}
Legislation enabling courts to confiscate or remove illegal gain has grown rapidly across a wide range of countries within both civil and common law systems. We review these developments from an economic perspective and show that there are certain types of offence for which the removal of illegal gain may provide a valuable complement to more traditional sanctions such as fines. Offences committed sequentially in small units and where the 'victims' are unaware of offences as they are being committed may be very difficult (and costly) to detect. The probability of the offender being detected and convicted are correspondingly very low and the costs of getting convictions thus become very high. With a very low probability of detection efficient deterrence can be achieved only with extremely high fines. Some legislatures have preferred to give courts powers to remove illegal gain as an alternative means of increasing deterrence. We argue that the fact that these powers have most often been developed for offences such as environmental crime and drug trafficking lends support to our contention that more traditional sanctions have failed most conspicuously in areas of crime which tend to be repeated and 'victimless'.
\end{abstract}

\section{Introduction}

In the economic analysis of crime it has often been stressed that monetary sanctions, such as fines, are generally advocated as the most effective type of penalty. It has been recognized, however, that fines may not lead to an optimal deterrence if the wrongdoer is judgment proof. Thus, Shavell advocated the use of non-monetary sanctions. ${ }^{1}$ The most common non-monetary sanction is of course imprisonment. But imposing a prison sanction is costly. ${ }^{2}$ Many modern statutes regulating trade, markets or environmental pollution, however, provide

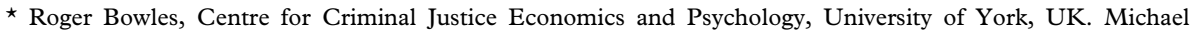
Faure, Maastricht University, The Netherlands. Nuno Garoupa, School of Economics, Universidade Nova de Lisboa, Portugal and CEPR, London, UK.

${ }^{1} \mathrm{~S}$. Shavell 'Criminal Law and the Optimal Use of Non-Monetary Sanctions as a Deterrent', Columbia Law Review 1232-62 (1985).

${ }^{2}$ See R. Posner 'Optimal Sentences for White Collar Criminals', American Criminal Law Review 400-418 (1980) and critically J. C. Coffee 'Corporate Crime and Punishment. A Non-Chicago View of the Economics of Criminal Sanctions', American Criminal Law Review 418-76 (1980).
}

(C) The Author 2005. Published by Oxford University Press. All rights reserved. For permissions, please e-mail: journals.permissions@oupjournals.org 
for other non-monetary sanctions as well. In environmental law, one can for instance find the right of the judge to impose direct measures upon the convicted polluter, such as a duty to restore the harm committed, for instance by cleaning up a polluted soil. Sometimes these direct measures may go as far as the shutdown of a company. Some legislations also give the judge the possibility to order that his judgment should be published through mass media.

Although the application of these so-called direct sanctions (in the sense that they are expressly directed at a restoration of the harm done by the offender) still varies between the different European legal systems, one can certainly note an increasing use of those specific measures. For instance, if a polluter is prosecuted for illegally depositing waste, he will often be required by the court to clean up the waste he discharged. One particular sanction which gains increasing popularity in environmental law enforcement, but also in the fight against white collar crime in general, is the removal of illegal gain. The idea is that the offender should not be left with the profits he has made by committing the crime. The application of this specific sanction raises a number of questions in legal doctrine and case law. However, the removal of illegal gain is a sanction that has now been widely adopted in many countries. In this article we wish to examine this trend from a law and economics perspective. ${ }^{3}$ The economic model of crime we use is based on the structure proposed originally by Becker, ${ }^{4}$ as refined and extended in a long series of increasingly sophisticated papers reviewed by Garoupa. ${ }^{5}$

The traditional economic analysis of criminal law treats crime as the result of a cost-benefit analysis by the criminal to which criminal law should react by threatening with a deterrent sanction. The sanction should more particularly be relatively high to compensate for the low probability of the detection of the crime. Of course the probability of detection could be increased, but this is costly. ${ }^{6}$ Therefore economists traditionally prefer a maximal penalty ${ }^{7}$ given the high cost of raising the probability of detection. The preferred sanction for economists is clearly the fine. Fines are easy to impose and administer and hence only raise revenues and do not lead to additional costs. ${ }^{8}$ A key finding in the economic analysis of crime is therefore that an optimal enforcement policy will rely upon the use of monetary sanctions, usually taking the form of maximal fines. However, fines will clearly not lead to optimal deterrence in the case where the optimal fine would be higher than the wrongdoer's wealth and hence an insolvency problem arises. In

\footnotetext{
${ }^{3}$ We hereby build onto earlier joint work on this subject, see R. Bowles, M. Faure and N. Garoupa 'Economic Analysis of the Removal of Illegal Gains', International Review of Law and Economics (2000) vol. 20, 537-49.

${ }^{4}$ G. S. Becker 'Crime and Punishment: an Economic Approach', fournal of Political Economy, vol. 76, 169-217 (1968) and G. S. Becker 'Irrational Behaviour and Economic Theory', fournal of Political Economy 1-13 (1962).

${ }^{5}$ N. Garoupa, 'The Theory of Optimal Law Enforcement', Fournal of Economic Surveys (1997) vol. 11, $267-95$.

${ }^{6}$ See the seminal paper of G. Stigler 'The Optimum Enforcement of Laws', Fournal of Political Economy 526-36 (1970).

${ }^{7}$ A 'maximal' penalty involves, basically, a fine that exhausts all an offender's wealth: it is the highest possible monetary sum they can afford without going bankrupt.

${ }^{8} \mathrm{~A}$ strong case in favour of fines especially in case of economic crimes has been made by R. Posner 'Optimal Sentences for White Collar Criminals', American Criminal Law Review 400-18 (1980).
} 
that case Shavell has advocated the use of non-monetary sanctions, the most common of course being imprisonment. ${ }^{9}$ But imposing a prison sanction is costly. Therefore one can understand, as we just mentioned, that many modern statutes now provide for alternative types of non-monetary sanctions, some of which can even go as far as the shutdown of a company. Some legislations also give the judge the competence to order that the judgment should be published.

It is within this framework that one can understand the interest of modern legislators in the forfeiture of the gains that the wrongdoer obtained by committing the crime. Many policy makers and lawyers apparently believe that this removal of illegal gains is a highly effective weapon especially in the fight against organized crime since it removes the profit out of the crime. However, from an economic perspective, the question arises whether the case in favour of a removal of illegal gain is indeed that powerful. The low probability of detection of (organized) crime will still be a problem. Thus, the prospect of the removal of illegal gain from the offence may reduce, but it will certainly not eliminate, its $e x$ ante profitability. The goal of this article is hence to use the economic analysis of law to examine whether the tendency of modern legislators to rely increasingly on the removal of illegal gain can be understood. We will therefore examine to what extent the forfeiture of illegal gain fits into the traditional economic model of crime. We will argue that although it seems at first blush difficult to reconcile this new instrument with the traditional model, there are nevertheless circumstances in which the removal of illegal gain may become an attractive sanction. This may, so we will argue, inter alia be the case when the optimal fine would be too high (higher than the assets of the wrongdoer) or when fines are very costly to enforce. Moreover, we will argue that essential principles of criminal law prohibiting oppressive punishment or punishment viewed as disproportionate to the crime may prevent judges from imposing optimal fines. Economic theory teaches that in order still to achieve optimal deterrence the probability of detection would then have to be increased, meaning also that the costs of enforcement would rise. Thus we will argue that in those cases the removal of illegal gain may play a significant complementary role in addition to the fines. It can potentially close the gap between the maximum punishment that the law will allow and the fines that are sufficient to represent a credible deterrent. The removal of illegal gain will in that case be able to reach a credible deterrent at lower cost than by raising the probability of detection.

The article is structured as follows: section 2 provides some legal background concerning the forfeiture of illegal gain. It seems useful first to examine what, from a lawyers' perspective, might be the main goals of the removal of illegal gain. We can then compare these 'legal' goals with the economic perspective.

\footnotetext{
${ }^{9}$ See S. Shavell 'Criminal Law and the Optimal Use of Non-Monetary Sanctions as a Deterrent', Columbia Law Review 1232-62 (1985); also J. C. Coffee 'Corporate Crime and Punishment: a Non-Chicago View of the Economics of Criminal Sanctions', American Criminal Law Review 419-76 (1980) has advocated strongly against the sole use of fines.
} 
Section 3 will therefore provide the economic perspective by addressing how the removal of illegal gain fits into the traditional deterrence perspective. In the first part of section 3 we will argue that at first blush it is hard to fit the removal of illegal gain into the traditional economic model of crime. If this model would deter perfectly then the removal of illegal gain might not provide any additional benefit. However, in the second part of section 3 we will argue that there may be several possible reasons that explain why in certain circumstances the removal of illegal gain may constitute an additional deterrent. Section 4 will address the removal of illegal gain from a corrective justice perspective. This seems interesting since more particularly in the lawyers' perspective it is the corrective justice idea that is advanced as the basis for the removal of illegal gain. We will, however, argue that if this corrective justice perspective is taken too far sub optimal results could follow. Section 5 will provide some policy consequences from the analysis. Section 6 concludes.

\section{Legal Background}

Before addressing the removal of illegal gain from an economic perspective, in this section we will first of all provide some of the legal background and address some of the issues concerning the background of this new sanction.

First, we should point out that the notion of removal of illegal gain refers to the actual sanction imposed by a judge in a court of law. It should be distinguished from measures taken during the preliminary stages of an investigation or legal action, such as the seizure or confiscation of various goods, profits or gains. This confiscation during the preliminary stage may have several goals, such as guaranteeing that a removal of certain gains to the benefit of the state or another party is afterwards possible. But these steps, taken in the preliminary phase, as a procedural strategy, should be seen separately from the actual removal of the illegal gain, which is imposed by a judge as a substantive sanction after a criminal trial. It may well be possible to remove illegal gain when judgment is given or sentence passed, for example, even though these profits have not been confiscated during the preliminary investigation. This obviously may raise practical problems as far as the execution of a judgment ordering the removal of illegal gain is concerned. Hence, in practice a prosecutor will often try to seize the profits during the preliminary phase to guarantee successful execution of a judgment afterwards.

The removal of illegal gain has now been introduced into many criminal statutes in Western countries. ${ }^{10}$ The concept is not new: forfeiture was part of Roman law as early as $451 \mathrm{BC}$ and was also used by the ancient Greeks. In recent times, this specific sanction was usually introduced as a part of the fight

\footnotetext{
${ }^{10}$ For a good comparative overview see M. Kilchling (ed.), Die Praxis der Gewinnabschöpfung in Europa (Freiburg im Breisgau: Max Planck Institute for foreign and international criminal law, 2002).
} 
against organized crime and drugs. In some cases the possibility to remove illegal gains deriving from drug trafficking was explicitly introduced in drug legislation; in other cases this new sanction was introduced in a penal code, so that it could be applied to all kind of crimes. In 1970 Congress passed the first criminal forfeiture statutes in US history. In the UK forfeiture was introduced in the Drug Trafficking Offences Act 1986 and has been subsequently strengthened and extended to other areas of crime via the Criminal Justice Act of 1988 and 1993, the Drug Trafficking Act 1994 and the Proceeds of Crime Act of 2002. ${ }^{11}$

In other countries, one can notice the introduction of the sanction of removal of illegal gain, for a wide array of crimes, extending even to environmental statutes. Belgium introduced the sanction of removal of illegal gain through a statute of $17 \mathrm{July}, 1990^{12}$ directly into the penal code. ${ }^{13}$ Although the goal was primarily the fight against organized crime, it was made clear in the parliamentary proceedings that this sanction can be applied generally to all crimes and hence also to potential gains such as those made from violations of environmental statutes. Germany already knew a regulation of the 'Verfall' since 1975 in the Strafgesetzbuch. Again, it was introduced as a measure to confiscate illegally gained drug money, ${ }^{14}$ but had a general application as well. Other examples from the Netherlands, Denmark and Sweden show a similar pattern. ${ }^{15}$

However, the powers of courts to impose this sanction vary substantially across the areas of the law and also across jurisdictions. For example, as we will further discuss below, ${ }^{16}$ in some countries (such as the US) the proceeds of drug trafficking can be forfeited under civil powers, independently of any criminal proceedings. In other countries, such as the UK, the confiscation of such assets is only possible as a subsidiary part of criminal proceedings. Still, for most countries, the powers to remove illegal gain have only recently been introduced. Mostly they were first introduced into areas such as drug trafficking and only in some cases (see the example above) extended to a more general application. For instance, in 1970 in the case of the US and 1986 in the case of Britain, these powers of removing the illegal gain were still unavailable to the courts for drug trafficking.

The European country that has probably been at the forefront of the fight against organized crime and more particularly regulations concerning forfeiture of illegal gain is Italy. Given the problems with organized crime, Italy had already, by the end of the 1970s introduced a variety of legislation to-inter

\footnotetext{
${ }^{11}$ For commentary see E. Rees and A. Hall, Blackstone's Guide to the Proceeds of Crime Act 2002 (Oxford: Oxford University Press, 2003) and T. Millington and W. Sutherland, The Proceeds of Crime. The Law and Practice of Restraint, Confiscation and Forfeiture (2002).

${ }^{12}$ Moniteur Belge, 15 August 1990.

${ }^{13}$ It can now be found in article $42,3^{\circ}$ of the Belgian penal code.

${ }^{14}$ See J. Meyer, A. Dessecker and J. Smettan (eds), Gewinnabschöpfung bei Beteubungsmitteldelikten (Wiesbaden: Bundeskriminalamt, 1989).

${ }^{15}$ For a comparative analysis see M. Faure, 'Rechtsvergelijkende conclusies' in M. Faure and Th. De Roos (eds), De berekening van het wederrechtelijk verkregen voordeel uit milieudelicten (Den Haag: Sdu, 1998) 197-215.

${ }^{16}$ See section 5 .
} 
alia-punish participatory conducts in specific criminal associations. ${ }^{17} \mathrm{~A}$ part of this legislation also aimed at the removal of illegal gains and money laundering by criminal organizations. Italy already long knew a forfeiture of the proceeds of crime, but in the fight against organized crime the so-called 'la Torre' Act no. 646/1982 substantially extended the possibilities of forfeiture by introducing an Article 416 bis in the penal code. According to this provision there is a mandatory forfeiture of illegal gain in case of a conviction for participation in organized crime. Moreover, after the murder of the judges Giovanni Falcone and Paolo Borsellino in the summer of 1992, a new act no. 356/1992 again substantially extended the possibilities of confiscation by relaxing the connection between the origin of the crime and the confiscated assets. This new provision allows the confiscation of all assets available to the criminal which are disproportionate to his income or economic activity. However, after the constitutional court (Corte Costituzionale) declared this provision unconstitutional in a decision of 17 February, 1994 a new act no. 501/1994 was introduced to limit the possibility of this expanded confiscation to convictions for specific crimes related to organized crime. $^{18}$

The goal of this removal of illegal gain according to legal doctrine, is to achieve a so-called restitutio ad integrum. This means that the criminal should be put back in the situation in which he would have been if the crime had not been committed. This corresponds to the general notion that 'crime should not pay'. It was stated in legal doctrine that this restitutive goal could not fully be achieved with the imposition of other sanctions, such as the fine or the imprisonment. A fine may well be much lower than the profit gained by committing an offence and putting someone in prison obviously is no guarantee that the offender would not be left with the profits he made from a crime.

For offences such as theft the offender can be required to return stolen goods or to pay compensation to the victim of the crime. But for 'victimless crimes' 19 such as environmental pollution or drug trafficking the harm caused by crime is experienced by society at large rather than by individual victims. In that particular case the confiscation of the illegal gain thus replaces compensation to the victims.

This restitution goal of the removal of illegal gain also had important consequences for legal character. It is not usually considered a criminal sanction, such

\footnotetext{
${ }^{17}$ For an overview see S. Ardizzone, 'Criminal association in Italy: legislative significance and structural characteristics' in V. Militello and B. Huber (eds), Towards a European Criminal Law against Organised Crime, proposals and summaries of the joint European project to counter organised crime (Freiburg im Breisgau: Max Planck Institute for foreign and international criminal law, 2001) 43-46.

${ }^{18}$ For an overview of the legislative evolution in this respect in Italy see L. Paoli, 'Italien' in M. Kilchling (ed.), Die Praxis der Gewinnabschöpfung in Europa (Freiburg im Breisgau: Max Planck Institute for foreign and international criminal law, 2002) 239-95 and S. Hein and C. Visconti, 'Combating illegal proceeds in Italy' in V. Militello and B. Huber (eds), Towards a European Criminal Law against Organised Crime, proposals and summaries of the joint European project to counter organised crime (Freiburg im Breisgau: Max Planck Institute for Foreign and International Criminal Law, 2001) 89-97.

${ }^{19}$ See on this notion of victimless crime A. J. Ashworth, Principles of Criminal Law (Oxford: Oxford University Press, 4th edn, 2003) 52-54.
} 
as the fine or imprisonment, but a 'measure'. There are exceptions to this however: in France confiscation may be a 'supplement' to a penal sanction or, in some cases, even the primary sanction. ${ }^{20} \mathrm{~A}$ criminal sanction is said to have as its main objective the punishment of an offender in reaction to an act for which the offender is to blame. Measures are of a more corrective or restitutional nature and aim either at protecting the society or at restoring harm done. Therefore criminal sanctions are usually said to have a 'punitive' goal, whereas this is not the case for the measures. Another matter is obviously that for the offender some of these measures (such as notably the removal of illegal gain) may well have a very serious impact. Note that although in the US forfeiture is technically considered as a civil sanction, the US Supreme Court has recognized that forfeiture constitutes a significant punishment and is thus subject to constitutional limitations under the Eighth Amendment. ${ }^{21}$ From an economic perspective this difference between measures and punishment is obviously irrelevant.

The legal discussion can therefore sometimes be confusing for economists. Kilchling, for example, refers to criminal sanctions as 'punitive' whilst confiscation is referred to as 'preventive'. ${ }^{22}$ From the offender's perspective there may be little if any difference here: the possibility of removal of illegal gain can in some cases be just as effective a deterrent as a fine or a term of imprisonment.

In so far as the removal of illegal gain is regarded as a measure and not as a criminal sanction or punishment in the legal sense, it should in principle not aim at the punishment of the offender but at the restoration 'ad integrum'. Although this may seem like mere legal dogmatic distinction, it has important policy consequences in practice. If one accepts that the removal of illegal gain is merely a measure and not a punishment, this has important consequences for the amount which may be removed. If the goal of this measure is to put the offender back in the position he was in before he committed the offence, the measure should only aim at the removal of a profit. Hence, also the costs incurred by the criminal in committing the offence, should be taken into account. Thus, the judge could only order the removal of the net benefit gained by committing the crime. There is obviously an intense debate as to how this net benefit should be calculated in those legal systems that rely on the removal of the illegal gain as a measure. Analysing this net benefit may require detailed investigation and expertise. For present purposes, however, it is not the practical questions relating to how one should estimate the net benefit which are interesting from the perspective of the economic model of crime. From a theoretical point of view, the especially interesting question is whether and how this measure of removal of illegal gain fits into the traditional economic model of crime.

\footnotetext{
${ }^{20}$ See A. Kletzlen and T. Godefroy 'Confiscation and Anti-Money Laundering Regulations under French Law', European fournal of Crime, Criminal Law and Criminal fustice (1997) vol. 5, 273-80.

${ }^{21}$ Austin v United States, 509 US 602, 113 S.ct. 2801. For a comment see J. M. Scheb and J. M. Scheb II, Criminal Law and Procedure (Belmont: Wadsworth, 4th edn) 552-53.

${ }^{22}$ M. Kilchling 'Comparative Perspectives on Forfeiture Legislation in Europe and the United States', European fournal of Crime, Criminal Law and Criminal Fustice (1997) vol. 5, 342-61.
} 


\section{Economic Analysis: the Deterrence Perspective}

\section{A. The Traditional Model}

The traditional economic model of crime sees criminal decisions as the result of a cost-benefit calculation. Without going into detail on this literature ${ }^{23}$ the economic theory of crime holds, as we explained in the introduction, that the potential criminal makes an assessment of the expected costs and benefits of criminal behaviour and will make a decision on whether or not to commit the crime on the basis of the result of this balancing approach. Punishment is then simply seen as an instrument by which the costs for the potential criminal can be increased. As far as the costs are concerned, one has, however, also to take into account the costs of control, of judging criminals and imposing a sanction: in sum, the enforcement costs. From a policy perspective this model teaches that the criminal law can prevent crime by influencing the potential criminal's decision ex ante by either raising the probability of sanctioning (which is, however, costly) or by raising the sanction itself. ${ }^{24}$

This deterrence model of crime assumes that the criminal law can reduce crime by raising the costs of crime for the criminal. Thus, account is mostly taken of the potential net gain from the crime for the criminal and not so much of the harm caused through the crime. Criminal lawyers often incline, as a result, to the view that the economic model of crime may be particularly wellsuited to the analysis of profit-oriented criminality. ${ }^{25}$

Thinking about criminal law as a reaction to expected gain of the criminal seems logical since in many cases, especially with economic crimes, something may have happened which is socially undesirable (and should thus be deterred through the criminal law) but there is not always a clear proof of harm or measure of harm. The traditional example is a theft where the thief does not damage the stolen goods he took. ${ }^{26}$ From this it follows that the traditional economic model indeed largely focuses on the expected gain of the criminal. According to the traditional model an increase in the expected sanction should lead to a reduction of the expected net gain of the criminal who should thereby be

\footnotetext{
${ }^{23}$ For more on which see M. Faure, 'Criminal Law, Economics of Crime and Law Enforcement' in B. Bouckaert and G. De Geest (eds), Bibliography of Law and Economics (Dordrecht: Kluwer, 1982) 504-26; R. Bowles, Law and the Economy (Oxford: Martin Robertson, 1982) 54-105; N. Garoupa 'The Theory of Optimal Law Enforcement', Fournal of Economic Surveys (1997) vol. 11, 267-95 and M. Polinsky and S. Shavell 'The Economic Theory of the Public Enforcement of Law', Fournal of Economic Literature (2001) vol. 38, 45-76. For a recent development that applies the economics of signalling to explain crime, see D. Gambetta, Crimes and Signs: Cracking the Codes of the Underworld (Princeton, NJ: Princeton University Press, 2004).

${ }^{24}$ Thus, the economic model of crime is considered as a so-called deterrence model of crime. The criminological literature of course recognizes other models as well. For an overview see A. Dessecker, Gewinnabschöpfung im Strafrecht und in der Strafrechtpraxis (Freiburg im Breisgau: Max Planck Institut für ausländisches und internationales Strafrecht, 1992) 82-90.

${ }^{25}$ See again A. Dessecker, Gewinnabschöpfung im Strafrecht und in der Strafrechtpraxis (Freiburg im Breisgau: Max Planck Institut für ausländisches und internationales Strafrecht, 1992) 89.

${ }^{26}$ See further L. Haasen and R. MacAdams 'The Surprisingly Complex Case against Theft', International Review of Law and Economics 367-78 (1997).
} 
deterred. But the question is whether this justifies an ex post removal of illegal gain as a specific measure.

The traditional economic model emphasizes that the level of criminal liability imposed on an offender or criminal should be primarily based on the harm he caused and not on the gain he obtained from engaging in the harmful activity. The main point is that in order to achieve efficient internalization of the harm (that is, for the offender to care for the harm he causes), the sanction should be based on the harm and not on the gain. The general superiority of harm-based sanctions is shown to hold under very different rules and estimation (of harm and gain) errors. ${ }^{27}$ Therefore, the economic rationale for removal of illegal gain must be related to potential problems with harm-based sanctions.

\section{B. Removal of Illegal Gain and Deterrence}

From the traditional model of crime it follows that if the model would work optimally society would set the probability of a specific sanction times the amount of the sanction higher than the expected gain in which case the potential criminal (assumed to be well informed) would abstain from committing the crime. In this ex ante perspective there is hence no need for a removal of illegal gain ex post. Removal of illegal gain as an additional measure does not seem to serve any deterrence goal since deterrence can already be achieved with the ex ante threat of the imposition of fines or imprisonment. In fact, efficient punishment should be based on harm rather than on illegal gains.

There may, nevertheless, be some complementary arguments why the removal of illegal gain would still make sense from an economic point of view. Indeed, reality is often very much different than the assumptions of the traditional model of crime. Many criminals are (for a variety of reasons) apparently not deterred, whether because the probability of detection is perceived to be too low, the sanction is too weak or because they discount future punishments heavily relative to the immediate gains from crime. If a crime is nevertheless committed one could argue that the application of the slogan 'crime shouldn't pay' should, in any event, lead to a removal of any gain the criminal made through his crime. If the criminal knows ex ante that if he is caught, no matter what other sanctions are imposed, then the gain he made will be removed from him, this may ex ante provide additional incentives to avoid crime. Thus removal of illegal gain could outweigh the risk of a too low detection rate or a too low expected sanction. It should be noted that many legal systems which have introduced the removal of illegal gain, for instance the Netherlands, have specifically advanced deterrence as one of the goals of this measure. ${ }^{28}$ In this reasoning the removal of illegal gain

\footnotetext{
${ }^{27}$ See M. Polinsky and S. Shavell 'Should Liability be Based on the Harm to the Victim or the Gain to the Injurer', fournal of Law, Economics, and Organization (1993) vol. 10, 427-37.

${ }^{28}$ See S. Bakker, D. Van der Landen and Th. De Roos, 'Kader voor de beantwoording van de algemene vragen en jurisprudentie-analyse' in M. Faure and Th. De Roos (eds), De Berekening van het Wederrechtelijk Verkregen Voordeel uit Milieudelicten (Den Haag, Sdu Uitgevers, 1998) 36.
} 
fits into the deterrence model of crime. A weakness in this reasoning is, however, that there may of course still be a low probability of detection. In addition legal systems never provide a $100 \%$ certainty that the provision for removal of an illegal gain will be applied effectively. Thus the removal of illegal gain suffers from the same weaknesses as traditional sanctions. But still it could provide some marginal deterrence.

Some empirical studies by German criminologists have shown that the risk that removal of illegal gain might be applied ex post has hardly any ex ante effect on potential criminals in the decision whether or not to commit the crime. ${ }^{29}$

Another possibility would be to see the removal of illegal gain as a reaction to the harm caused as a result of the crime. The reasoning would be that the traditional sanctions (fines and imprisonment) do not sufficiently take account of the harm done. Some legal doctrine in the Netherlands held that the illegal gain made by the criminal is the mirror image of the harm done, ${ }^{30}$ but that seems hardly convincing. The goal of the removal of illegal gain is indeed to provide for some kind of restoration by taking away the gain from the criminal, but the measure does not aim at a reparation of damage. ${ }^{31}$

In sum: the traditional Becker model of crime takes into account the expected gain in an ex ante perspective because the expected sanction of the criminal should be higher than his expected gain to achieve deterrence. It seems, however, harder to explain why in an ex post perspective the gain that was effectively made through the crime should indeed be removed (for any reason different than using illegal as well as legal income to pay fines). Thus, one could at first blush argue that the removal would only be a costly transfer of funds without any additional influence on the incentives to prevent crime. This is obviously too simplistic an approach if only because the assumptions of Becker's world are almost never fully met in practice. Let us therefore now have a look at arguments that could explain why removal of illegal gain makes sense from a deterrence perspective.

\section{Possible explanations}

The main result of Becker's analysis is that when the sanction is costless to impose it should be taken to its maximum. The reason behind this is simple: since there are two ways of increasing deterrence, either raising the probability of detection or raising the sanction, it is cheaper to raise the sanction if this can be done at no cost. Consequently in this hypothesis the maximal fine should be determined by the individual wealth of the injurer and by the illegal gain he

\footnotetext{
${ }^{29}$ See the interesting study by J. R. Smettan, Kriminelle Bereicherung in Abhängigkeit von Gewinnen, Risiken, Strafen und Moral (Freiburg im Breisgau: Max-Planck- Institut für internationales Strafrecht, 1992) see especially pages 184-210; see also W. Perron 'Vermögensstrafe und Erweiterter Verfall', furistenzeitung (1993) 919-20.

${ }^{30}$ See S. Bakker, D. Van der Landen and Th. en de Roos, 38-40.

${ }^{31}$ So also G. Stessens, De Nationale en Internationale Bestrijding van het Witwassen, Onderzoek naar een meer effectieve Bestrijding van Profijtgerichte Criminaliteit (Antwerpen: Intersentia, 1997).
} 
obtained as a result of the offence. In this perspective it could easily be argued that removal of illegal gain is part of the efficient policy since it enables the probability of detection to be set at a lower level than would be necessary otherwise to achieve an optimal deterrence. However, the analysis equally makes clear that the removal of illegal gain alone is not optimal. Part of the sanction must indeed also affect the legal income of the criminal and not only the income generated with the criminal activity. The reason is, in economic terms, that there must be a so-called opportunity cost for potential offenders. If the sanction were limited to the removal of the illegal gain, in the worst possible state of affairs the offender would still get what he had before committing the offence. Thus, crime would simply become an attractive lottery. Therefore the removal of illegal gain can be an additional measure but does not eliminate the use of traditional fines. The most important reason behind the removal of illegal gain is therefore that it can increase the effectiveness of criminal policy by permitting the government to save on detection and punishment expenditure. In the absence of the additional possibility to impose the removal of illegal gain the probability of detection would have to be increased, which is more costly. Thus it can be argued that the removal of illegal gain serves the purpose of optimal deterrence for two reasons:

It is a costless transfer from offenders to the government (and therefore it does fit into the traditional Becker model) and, maybe more importantly:

It increases the effectiveness of detection, enabling a reduction in expenditure on law enforcement

Thus far we have argued that the removal of illegal gain should be part of optimal law enforcement in a deterrence perspective as a way to pay for higher fines. We can, however, take the analysis further and relax the assumption that removing illegal gains is a costless activity for the government. Suppose that removing illegal gains is costly for the government (for instance because it is difficult to find out where the illegal gain has exactly gone to or it has already been spent by the offender), ${ }^{32}$ but removing simply the legal wealth of the offender would be costless (simply because the wealth would be visible and available for seizure). ${ }^{33}$ The efficient solution is then to confiscate the entire wealth of the offender (the correct legal technique to do this would probably be to set the maximal fine equal to the entire wealth) and to use the removal of illegal gains to complement the deterrent effect of sanctioning. In sum, if removing the illegal gain is more costly than just removing the entire legal wealth of the offender the use of the removal of illegal gain as part of the monetary sanction becomes less attractive.

There are, however, a few other elements that can influence the efficiency of the use of the removal of illegal gain that we should discuss:

\footnotetext{
${ }^{32}$ See the discussion above in section 2.

${ }^{33}$ Here we follow the analysis by M. Polinsky and S. Shavell 'The Optimal Use of Fines and Imprisonment', fournal of Public Economics (1984) vol. 24, 89-99.
} 
(i) Administrative cost

If there were significant differences between the administrative costs in applying wealth-based sanctions as compared with forfeiture (although we cannot see directly why there should be such differences) then this may constitute a reason for preferring one sanction to the other. If the administrative costs of imposing fines were higher than for the removal of illegal gain, then this may justify the imposition of less than maximal fines and a more frequent use of the removal of illegal gain. ${ }^{34}$

\section{(ii) Costly verification}

A related point is that it may be more costly to observe illegal gains than legal income. If that is the case, this can be an argument for applying the traditional fine rather than the removal of illegal gains. Assessing legal wealth (e.g. real estate and legal income) could relatively easily provide authorities with information, but assessing illegal gains can be more complicated. Note, however, that in some cases it may be difficult to make a clear distinction between legal wealth and illegal gain. A drug dealer, for example, may run a small legal business, say a grocery shop, with the result that the proceeds from drug selling are mixed with the revenue from selling groceries. In those cases, particularly if the quality of business record-keeping is low, it may be very difficult for authorities to distinguish the legal gains within the small business from those generated by selling drugs. ${ }^{35}$

It will usually be more complicated to audit the gains acquired from illegal activities than the gains from legal activities. The simple reason is that offenders will often engage in avoidance activities to make it more difficult for the government to identify and verify illegal gains. Hiding illegal gains is of course much easier because they result from illegal deals that, from the authorities' viewpoint, never took place. Legal transactions are always subject to various recordkeeping or income declaration requirements and this makes it more difficult to hide legal income. These avoidance activities increase the social cost of crime. This may be an argument against a complete removal of the illegal gain. ${ }^{36}$ If removal of illegal gains were not complete, this would reduce avoidance by the offender and consequently verification costs.

\section{(iii) Identification of social damage}

A crucial assumption in the law enforcement model is that the social damage caused by a crime is observable and costlessly verifiable. Although we indicated that the criminal will, from the Beckerian perspective, base his decision on

\footnotetext{
${ }^{34}$ Here we refer to other costs than the costs to find out the amount of legal wealth versus the illegal gain, the issue we just discussed.

${ }^{35}$ We are obviously assuming that selling drugs is a criminal activity, which is not the case any longer in all countries.

${ }^{36}$ See also A. S. Malik 'Avoidance, Screening and Optimal Enforcement', Rand fournal of Economics (1990) vol. $21,341-53$.
} 
whether or not to commit a crime on a comparison of his expected gain with his expected costs, from society's point of view the social damage does play a role for crime policy. It is particularly important in the decision about how much to spend on law enforcement, crime control and detection. However, in some circumstances it may be very costly to identify the scale of the crime and more particularly the damage the particular crime has caused. In those cases it may be difficult to base the sanction on the damage caused by the crime. This difficulty in assessing the damage may thus well motivate the use of illegal gain as a basis for the assessment of a sanction. This is the case if it is cheaper or easier to assess the gain acquired by the offence than to measure the harm. This seems to be the case with, for example, environmental crimes. It might also be the case for crimes involving illegal gambling, prostitution and drug dealing because of the under-reporting of such crime.

\section{(iv) Enforcement errors}

The use of the illegal gain obtained from the offence as a basis for the sanction can also have the benefit that it reduces errors in law enforcement. Kaplow and Shavell pointed out that increased law enforcement and accuracy of the sanction are regarded as substitutes in achieving deterrence. ${ }^{37}$ Using illegal gains as a measure for the sanction can thus mean that the accuracy is increased; this may therefore reduce enforcement costs.

\section{(v) Money laundering}

An argument can also be made that removing illegal gain may plausibly reduce criminal activities in the future. Indeed, legal wealth is more likely to be reinvested in the legal sector whereas illegal wealth is more likely to be reinvested in the illegal sector. One could therefore hold that the removal of illegal gains avoids that these gains are reinvested in other illegal activities. However, a part of illegal gains is also laundered into the legal sector. Most legislation also allows the removal of illegal gains when they have been invested elsewhere. ${ }^{38}$ In those cases the removal of illegal gains may have an opportunity cost. An example would be where a criminal has invested his illegal gains in a legitimate, cashhungry business such as property development. If the business has suddenly to be liquidated, then losses may result from the interruption to construction work as a new financier is sought. One could argue that by exempting from removal the illegal gains that have been reinvested in legal activities the government might reduce criminal activities in the future. However, this would effectively mean that an operation of laundering money would be rewarded. Thus the expected sanction would be reduced, thereby diluting deterrence and increasing criminal activities in the future. In sum the policy to remove illegal gains, even

\footnotetext{
${ }^{37}$ L. Kaplow and S. Shavell 'Accuracy in the Determination of Liability' (1994) Fournal of Legal Studies, vol. 37, 1-15.

${ }^{38}$ This is in the legislation referred to as the right to 'follow' the illegal gain.
} 
when they have been laundered into the legal sector, can be upheld from a deterrence perspective.

\section{(vi) Marginal deterrence}

Economists have often stressed the importance of marginal deterrence. ${ }^{39}$ This notion, which goes back as far as the ideas of Beccaria, refers to the fact that when faced with the possibility of committing one of several harmful acts individuals must have clear incentives to chose the least harmful act. ${ }^{40}$ As a consequence fines should be lower for less harmful offences and should be more severe for more harmful offences. ${ }^{41}$ This, by the way, corresponds with the notion of proportionality of sanctions in criminal law.

In principle a removal of illegal gains should also satisfy marginal deterrence. One can argue that the removal of illegal gain can help the government to satisfy the principle of marginal deterrence. To see why, assume that there were no removal of illegal gains. In that case the government should only apply a fine equal to entire wealth for very harmful offences. Conversely, for less harmful offences the fine should be less than the entire wealth to meet marginal deterrence objectives. If removal of illegal gain is possible the government can couple this measure of removal with a fine imposed on legal income for each offence. With this policy, where both a fine and removal is applied, a different sanction is applied for each offence and marginal fines can be applied. In other words: removal of illegal gain removes the necessity to apply fines equal to the entire wealth for almost all (harmful) offences and allows for a more differentiated approach. Thus the removal of illegal gains facilitates satisfying marginal deterrence.

\section{(vii) Co-operative crimes}

Many crimes to which the removal of illegal gains is enforced by governments are committed by two or more individuals, and are thus the product of cooperative behaviour between criminals. An important way to deter these crimes is to introduce and develop distrust between criminals, thereby exploiting the instability of an illegal cartel. ${ }^{42}$ Asymmetric removal of illegal gain plays an

\footnotetext{
${ }^{39}$ See inter alia R. Cooter and T. Ulen, Law and Economics (Addison-Wesley, 3rd edn, 2000) 446 and F. Easterbrook 'Criminal Procedure as a Market System' (1983) fournal of Legal Studies 294.

${ }^{40}$ The classic example is that if breaking into a house and murder were both punished with an imprisonment term of 20 years, those who break into a house and are discovered would have an incentive to kill the victim. The murder would reduce the likelihood of their being caught and convicted, but would not lead to any additional punishment if they were caught; hence there would be no marginal deterrence.

${ }^{41}$ Here one recognizes again that the type and amount of the sanction traditionally corresponded with the harm caused by the offence instead of with the gain obtained by the criminal.

${ }^{42}$ On the economic design of enforcement polices to tackle illegal cartels and organized crime, see N. Garoupa 'The Economics of Organized Crime and Optimal Law Enforcement', Economic Inquiry, 38, 278-88 (2000); R. Cooter and N. Garoupa, 'The Virtuous Circle of Distrust: A Mechanism to Deter Bribes and Other Cooperative Crimes' (November 7, 2000), Berkeley Ohlin Program in Law \& Economics, Working Paper 32 http://repositories.cdlib.org/blewp/32; and more generally D. Gambetta, Crimes and Signs: Cracking the Codes of the Underworld (Princeton, NJ: Princeton University Press, 2004).
} 
important role in this respect. There are three advantages to consider. First, asymmetric removal of illegal gain makes the payoff from cooperation in an illegal network more uncertain, thus raising the costs of complying with the organization, and lowering the costs of defecting for risk-averse criminals. A second aspect is that asymmetric removal makes the distribution of illegal gains more unequal among criminals, thus inducing the criminals who do less well to envy those who do relatively better and eventually defect from the current illegal cartel to form a new organization. This possibility raises the likelihood of splits and internal fights in the criminal word, and guarantees more distrust diluting the possibility of a stable agreement. In this context, signalling cooperative behaviour in the criminal world is more costly and less likely to take place. Finally, asymmetric removal of illegal gain can be part of a broader policy of creating incentives for defection, including amnesty plus bounty for those who provide evidence to the government that helps prosecution and punishment of criminals. Full removal of illegal gain is not consistent with asymmetric removal and would curtail the set of possible policies to enhance distrust among criminals.

In sum there are several reasons why some (but not always complete) removal of illegal gains can serve goals of optimal deterrence. Removal of illegal gains: (a) increases the effectiveness of detection; (b) provides a good proxy for the amount of social damage in cases where the damage is hard to assess; (c) reduces enforcement errors; (d) provides the government with an instrument to satisfy marginal deterrence and (e) helps the government in implementing a policy of distrust among criminals to fight illegal cartels. Nevertheless, we also indicated that there are costs to the removal of illegal gains, namely: (a) observation and verification costs, which may indeed be higher to assess illegal gains than legal income and wealth; (b) offenders could engage in costly avoidance activities; (c) removing illegal gains reinvested in legal activities usually has an opportunity cost and (d) it may deter money laundering (removal of illegal gain has the effect of reinvesting illegal gain in illegal activities to reduce the chances of detection of those gains).

\section{A Corrective fustice Perspective}

So far we have taken a deterrence approach to the removal of illegal gain. Indeed the arguments made above, namely that the removal of illegal gain can increase deterrence, do not rest on 'corrective justice' objectives or 'fairness' considerations. Another possible approach is to discuss removal of illegal gains in the context of fair law enforcement and corrective justice.

It is well known, especially in the economic analysis of accident law, that many scholars have stressed that law should not only lead to deterrence of accidents, but also provide corrective justice. This means, stated simply, that the law should also aim at restoring the social imbalance which has been created through an accident. Corrective justice then is often used as an argument in tort 
law to force an injurer to compensate the victim ${ }^{43}$. This Aristotelian notion of corrective justice might, compared with the traditional deterrence model, provide more easily a theoretical basis for the removal of illegal gain. One could argue that the corrective justice-idea has to be interpreted in such a way that when it is established ex post that a criminal has obtained illegal gain as a result of an illegal act, this gain should be removed from him. Through this removal the social balance which had been harmed as a result of the crime could be restored in the sense that a restitutio ad integrum is achieved. Thus it means that the 'crime shouldn't pay' idea in a corrective justice perspective not only takes into account the gain ex ante, but also ex post. The theoretical basis for this ex post removal is then, however, probably no longer the deterrence view point.

Support for this corrective notion as a theoretical foundation of the removal of illegal gain can be found in legal doctrine. Some authors note that the removal of illegal gain rests on the 'fundamental notion of justice that crime shouldn't pay' and 'justice requires that in all cases the criminal should be put back in the status quo ante. ${ }^{44}$

The question arises as to the extent to which the deterrence approach presented above is reconcilable with this corrective justice perspective. There may be cases in which a removal of illegal gains out of fairness or corrective justice considerations could conflict with optimal deterrence. The simple reason is that the government may argue that removal of illegal gain should take place in all cases and should always be complete because it is fair to do so. The result may be a relatively too severe removal of illegal gain with, e.g. a corresponding less severe fine on legal wealth or a reduction of enforcement expenditures. We indicated when discussing the deterrence perspective that a $100 \%$ removal is not always efficient, since this depends on a number of elements, one of them being the amount of legal wealth available and also the costs of the removal of illegal gain versus the cost of imposing a fine on legal wealth. Hence, a general rule of a total removal of all illegal gain in all cases based on a corrective justice perspective may in some cases be in conflict with the deterrence perspective. How seriously one considers this conflict of course depends on how the government weighs deterrence objectives versus fairness considerations. ${ }^{45}$

\footnotetext{
${ }^{43}$ This has been defended among others by F. A. Epstein, 'A Theory of Strict Liability' (1973) fournal of Legal Studies 151-204 and C. G. Veljanovski, 'The Economic Theory of Tort Liability-Towards a Corrective Justice Approach' in The Economic Approach to Law, P. Burrows and C. G. Veljanovski (eds) (London: Butterworths, 1981) 125-50 and has been seriously criticized by Posner (R. Posner, 'The Concept of Corrective Justice in Recent Theories of Tort Law' (1981) fournal of Legal Studies 187-206). See on this topic also G. Schwartz, 'The Ethics and the Economics of Tort Liability Insurance', Cornell Law Review 313-65 (1990). See for a more general discussion L. Kaplow and S. Shavell, Fairness versus Welfare (Cambridge, MA, Harvard University Press, 2002) (also Harvard Law Review, 2001, vol. 114/4, 961-1388. And see A. M. Polinsky and S. Shavell 'The Fairness of Sanctions: some Implications for Optimal Enforcement Policy', American Law and Economics Review (2000) vol. 2, 223-37.

${ }^{44}$ G. Stessens, 60-61.

${ }^{45}$ The notions of corrective justice and wrongful gain have also been discussed in the context of tort law. In that respect a distinction is made between on the one hand liability in tort and on the other hand recovery of wrongful gains based on unjust enrichment. See on the controversies concerning these issues J. Coleman 'Corrective Justice and Wrongful Gain' (1982) Fournal of Legal Studies vol. 11, 421-40.
} 


\section{Policy Consequences}

What can we learn so far, at the policy level, from the deterrence approach presented in section 3 and the example we just discussed? Section 3 showed that the removal of illegal gain may add to deterrence and that the optimal amount of removal may depend on the legal wealth available to pay the fine and on other elements, such as the enforcement costs involved. We argue that there are various developments at the legal policy level making the removal of illegal gain a more attractive legal instrument, more particularly in areas such as drug trafficking.

It is a legal reality that political or constitutional constraints may require that punishment be proportional to the offence for which a conviction is obtained. Punishments which are very high relative to the value or severity of the offence may be regarded as cruel, unusual or disproportional and thus be rejected or reduced by Appeal Courts. This may explain why there can be a reluctance on the part of courts to set the maximal fines as proposed by the Becker model. Given the relatively modest probabilities of detection and conviction, e.g. in the area of drug trafficking, an under-deterrence will follow unless draconian sanctions could be imposed which is, for obvious reasons, impossible. However, the retreat at the criminal policy level from tougher criminal sanctions has at the same time, as we sketched in section 2 , been accompanied by a more widespread adoption of complementary sanctions, of which confiscation of illegal gain is one. Constraints on applying very high sanctions can thus explain why legislators are increasingly interested in alternative sanctions, such as the removal of illegal gain. This can obviously also be explained by bankruptcy constraints. Judgement-proof defendants will not alter their behaviour once fines reach a certain level, because they have nothing further to lose. This is also likely to happen in the corporate sphere, where corporate actors are generally protected by the limited liability of the corporation. ${ }^{46}$ Moreover, criminal law only allows the financial situation of the individual defendant to be taken into account when setting a fine. Hence, in legal systems without corporate criminal liability (such as Germany) this leads to fines being based on the assets of the individual employee rather than the higher wealth of the corporate entity. These relatively low fines for what are in fact corporate crimes may therefore result in under-deterrence. Thus, one can understand why, at the policy level, given the impossibilities to apply the maximal fines from the Becker model, alternative sanctions such as the removal of illegal gain are applied.

One can especially understand the focus on illegal gain within the sanction when so-called 'victimless crimes' are considered. In those cases, such as drug trafficking, the harm caused by the crime is experienced by society at large and is hard to measure. Thus the harm or damage caused by the crime cannot be used

\footnotetext{
${ }^{46}$ See S. Shavell 'The Optimal Level of Corporate Liability given the Limited Liability of Corporations to Penalise their Employees', International Review of Law and Economics (1997), vol. 17, 203-13.
} 
readily to determine the sanction in a particular criminal case. Thus one can understand that especially in case of these victimless crimes the confiscation of illegal gain is applied. In that case it also replaces compensation of victims. For example, the powers of confiscation introduced into the criminal law in England under the Drug Trafficking Offences Act 1986 include a Confiscation Order requiring an offender to pay a sum equal to the global value of his or her proceeds of crime, or to the total value of the 'realisable property' where this is lower. These proceeds may be the result of thousands of small transactions involving sales to willing buyers and thus very little crime reported to the police, but represent very substantial costs to third parties who have suffered the consequences of the drug-taking.

Under the Drug Trafficking Act 1994 which replaced the 1986 Act, measures were taken to close various loopholes and to strengthen the legal powers available to courts. Any money or property received in connection with drug trafficking, not just profits or proceeds of trade, were to be included in the court's assessment of trafficking assets. In addition, the traditional burden of proof is reversed and the defendant has to prove that any property in their possession over the six years prior to the offence is not the proceeds of drug trafficking. The Act also created a new offence of failing to disclose to a police officer a knowledge or suspicion (arising in the course of business) that another person is engaged in drug money laundering. ${ }^{47}$

A somewhat different legal approach to the proceeds of drug trafficking with the same underlying motivation is to be found in the US. Rather than using the English approach of treating confiscation strictly as a complementary sanction available only in the event of a criminal conviction for trafficking, the US system allows the use of quite distinct civil powers entirely independently of any criminal proceedings. In legal terms, forfeiture in the US is an in rem proceeding as distinct from an in personam proceeding under criminal law: it is directed at the assets rather than at the criminal. The net result is that the courts can make use of the lower standard of proof required under civil law and can gather proceeds from a series of presumed offences.

From an economic perspective this substitution of (quasi) civil penalties for criminal ones may be interpreted as a way of making sanctions more sensitive to the wealth of the individual offender and thus bringing them closer to the maximal fines of the Becker model. If an offender is contemplating an offence expected to raise substantial illegal gains which are high in proportion to his original wealth then, from an ex ante perspective, it can be inferred that the removal of illegal gain even combined with a moderate fine (taking into account the ex ante lower wealth) will have as powerful a deterrent effect as the maximal fine of the Becker model.

Hence, one can understand that in many jurisdictions in addition to criminal confiscation legislators have been creating the possibility for civil recovery of the proceeds of unlawful conduct. That is precisely also the aim of the recent UK

\footnotetext{
${ }^{47}$ Section 18 of the Criminal Justice Act 1993.
} 
Proceeds of Crime Act 2002, which creates an entirely new high court jurisdiction for the making of a 'recovery order'. This order enables the director of the assets recovery agency to recover property which is 'property obtained through unlawful conduct'. ${ }^{48}$ This part of the Act has not entered into force yet, since it also needs new rules of civil procedure and evidence. The commentators on the Proceeds of Crime Act argue that this civil recovery can be considered an easy alternative to criminal confiscation. ${ }^{49}$

Of course a problem in practice with both fines and with the removal of illegal gain is that offenders will do anything they can to avoid the application of these sanctions. An important point here is that 'career criminals' or 'organized criminals' are likely to be able to find strategies that raise the costs to enforcement agencies of detecting monetary crime and of assembling evidence sufficiently compelling to support serious charges. Particularly in cases like environmental pollution or drug trafficking offences are likely to be sequential. It is exactly in those cases that illegal gain may act as a useful indicator for enforcement purposes because it is easier to measure than harm caused or even the number of offences committed. This argument has a close parallel to Shavell's point ${ }^{50}$ that it might sometimes be cheaper to monitor emissions from a chemical plant continuously ex ante than to try to estimate care levels, or pollution levels attributable to the plant ex post. But although the removal of illegal gain may thus especially be important in case of sequential offences it is equally those 'organized criminals' likely to engage in sequential offences who will make serious efforts to avoid detection. The success of this instrument of the removal of illegal gain will to a large extent also depend upon improved technology and increasingly stringent reporting requirements on financial institutions. These may make it easier to track asset movements and to trawl asset inventories. Although this may be offset to some degree by it becoming easier for offenders to shift funds between accounts or between assets to frustrate enforcement agencies, it may still be that confiscation comes to look a more attractive sanction than criminal punishment alternatives.

Precisely because confiscation of illegal gains might be a more effective sanction than traditional fines to address 'career criminals' one can understand that, as was mentioned above, more particularly in Italy, important legislative steps have been taken, as a result of the fight against organized crime, to address criminal careers. ${ }^{51}$ Hence, one can understand that the Italian legislator more

\footnotetext{
${ }^{48}$ Section 240 of the Proceeds of Crime Act 2002

${ }^{49}$ See E. Rees and A. Hall, The Proceeds of Crime Act 2002, 117-19 and T. Millington and M. Sutherland Williams, The Proceeds of Restraint, Confiscation and Forfeiture (Oxford: Oxford University Press, 2003) 341-52

${ }^{50} \mathrm{~S}$. Shavell 'The Optimal Structure of Law Enforcement', fournal of Law and Economics (1993) vol. 36, $255-87$.

${ }^{51}$ See inter alia S. Ardizzone, 'Criminal association in Italy: legislative significance and structural characteristics' in V. Militello and B. Huber (eds), Towards a European Criminal Law against Organised Crime, proposals and summaries of the joint European project to counter organised crime (Freiburg im Breisgau: Max Planck Institute for foreign and international criminal law, 2001) 43-52 and A. Ingroia, 'Criminal association and organised crime: the Italian experience' in V. Militello and B. Huber (eds), Towards a European Criminal Law against Organised Crime, proposals and summaries of the joint European project to counter organised crime (Freiburg im Breisgau: Max Planck Institute for foreign and international criminal law, 2001) 53-55.
} 
particularly with the law decree no. 306/1992 introduced a rebuttable presumption as to the unlawful origin of the confiscable assets in cases where the property of the accused is not commensurate with his or her declared income or economic activity. ${ }^{52}$ From an economic perspective one can hence understand that various legislators, particularly in Italy, have introduced models of so-called 'extended' confiscation especially as an instrument in the fight against organized crime. The extension of the confiscation to other gains than the one obtained with the particular crime for which there is a conviction may be an appropriate instrument to address career criminality.

\section{Conclusion}

The growth of legislation enabling courts to confiscate or remove illegal gain is a striking phenomenon seen across a wide range of countries within both civil and common law systems. Confiscation is a transfer occurring after a crime has been committed and, on the face of it, has little to add by way of deterrence if courts are already applying efficient sanctions since these will already incorporate a measure of illegal gain. But if, for some reason, the courts have been applying fines which exclude any element of illegal gain, then a role for confiscation may emerge. We have argued that there are certain types of offence for which the removal of illegal gain may provide a punishment superior to more traditional sanctions such as fines of the narrow kind based more on the offence than the offender. Offences committed sequentially and where the 'victims' are unaware of offences being committed may be very difficult (and costly) to detect. The probability of the offender being detected and convicted are correspondingly very low and the costs of getting convictions thus become very high. With a very low probability of detection efficient deterrence can be achieved only with extremely high fines. Some legislatures (particularly those in countries where high fines cannot be enforced) have preferred to give courts powers to remove illegal gain as an alternative means of increasing deterrence. We argue that the fact that these powers have most often been developed for offences such as environmental crime and drug trafficking lends support to our contention that more traditional sanctions have failed most conspicuously in areas of crime which tend to be repeated and 'victimless'.

From a law enforcement perspective it may be comparatively cheaper to monitor the accumulation of assets from crime than it is to monitor the crimes themselves particularly in fields such as drug trafficking where reporting of illegal activity may be weak. The costs of this (asset) monitoring can sometimes be shifted to the financial sector by imposing on banks and other institutions a duty

\footnotetext{
${ }^{52}$ See G. Fiandaca and C. Visconti, 'Theoretical and criminal policy foundations for a model 'extended' confiscation in the ambit of organised crime' in V. Militello and B. Huber (eds), Towards a European Criminal Law against Organised Crime, proposals and summaries of the joint European project to counter organised crime (Freiburg im Breisgau: Max Planck Institute for foreign and international criminal law, 2001) 79.
} 
to report transactions which they suspect to involve the proceeds from crime. There may thus be certain 'economies' in law enforcement if evidence used to detect criminals can also be deployed in identifying suitable targets for confiscation. The result is that law enforcement agencies will probably use a mix of investigative methods including asset monitoring. But the greater use agencies make of the latter and the greater the degree to which courts endeavour to confiscate illegal gain, the stronger are the incentives for criminals to take evasive action by avoiding legitimate financial intermediaries or changing the types of transaction they make. We show that this may result in a less efficient channelling of investment resources.

The removal of illegal gain is an integral part of the efficient deterrence programme of maximal fines required by the optimal enforcement policies generated by the Becker model. Legal practice has not traditionally been very sympathetic to such policies which are often thought of as capricious and oppressive. The preference has been for a sentencing policy which takes some account of the offender's means but which takes account also of previous criminal record and particularly the gravity of the offence of which the offender is convicted. Only rarely does this amount to anything like a maximal fine. One way of interpreting the widely observed trend to extend the use of removal of illegal gain is to think of it as a way to bias sanctions more closely to offender means and to increase the scale of sanctions. This can help compensate for the weak deterrence which may otherwise be found in areas such as illegal trading where convictions probabilities are low and the fines imposed are low in relation to the gains from crime. 
